\title{
Low Level Laser Therapy for Non-Invasive Dental applications: A Review
}

\author{
Munna Khan*, Naved Alam** \\ *(Electrical Engineering Department, JMI, Delhi-110025 \\ ** (Electrical Engineering Department, JMI, INDIA
}

\begin{abstract}
Laser therapy has an excellent track record in medical applications, and it has made its unmatched position by treating several dental problems. Laser devices has successfully improved healthcare in medical field by providing non-invasive and painless ways of treatment. In this paper the systematic review has been conducted for the comparative study of Laser technology using Low Level Laser Therapy in dental applications. For this the database is looked through utilizing Pubmed, IEEE, Science Direct utilizing foreordained inquiry term Low Level Laser Therapy and Laser treatment in dental treatment for the most part centered around laser diode dental treatment. Our clinical comparative study shows that Laser therapy is a painless treatment which may help fast healing in less time as compare to traditional treatment.
\end{abstract}

Keywords-LLLT, Dental, Laser application, Laser Parameters, soft tissue laser.

\section{INTRODUCTION}

Word "laser" is an abbreviation for Light Amplification by the Stimulated Emission of Radiation. The primary low-level remedial laser was created in 1962. Before the finish of the 1960's, Endre Mester in Hungary was announcing an improved recuperating of wounds through low-level laser radiation. From that point forward, researchers and specialists around the globe have been utilizing laser light to treat conditions which can influence all age gatherings $[1,2]$.

Low Level Laser therapy is the use of coherent beams of laser light is used to diagnose or treat medical conditions. Lasers have four main parts: the active medium, the excitation mechanism, the feedback mechanism, which is usually a reflective mirror, and the output coupler. Laser light is created by controlled emissions which allows a doctor to target a specific tissue, as the light is focused and can be turned on and off easily. Lasers are treated in two ways, contact and noncontact mode. Contact lasers work by sending a light through a fiber tip or sapphire tip. The tip absorbs energy and becomes hot. When the hot tip touches any live tissue in the body, the target cells are vaporized, which is the removal of tissue through the conversion of a solid to a gas. Noncontact lasers do not touch the tissue [3]. They operate by transferring laser light as radiant energy in a single beam to the tissue. Heat is generated after the laser's radiant energy is absorbed by the targeted tissue. The light vitality created by a laser can have four distinct communications with an objective tissue: Reflection, Transmission, Scattering, and Absorption. At the point when a laser is retained, it lifts the temperature and produces photochemical impacts relying upon the water substance of the tissues. At the point when a temperature of $100^{\circ} \mathrm{C}$ is reached, vaporization of the water inside the tissue happens, a procedure called removal. At temperatures underneath $100^{\circ} \mathrm{C}$, yet above around $60^{\circ} \mathrm{C}$, proteins start to denature, without vaporization of the hidden tissue. On the other hand, at temperatures above $200^{\circ} \mathrm{C}$, the tissue is got dried out and afterward consumed, bringing about an unfortunate impact called carbonization.

Low Level Laser Therapy (LLLT) is an application of light over the injuries or lesions to improve the healing and it can regenerate damage cell tissue or it can destroy unwanted cells like a cancerous cell. At the point when the right force and treatment times are utilized, laser light can lessen oxidative pressure and builds the Adenosine Tri-Phosphate which improves cell's digestion and expands its wellbeing [6]. LLLT gadgets incorporate the gallium arsenide ( $\mathrm{GaAs})$, gallium aluminum arsenide infrared semiconductor (GaAlAs), and helium neon (HeNe) lasers. Our focus is on Diode laser because of its wavelength spectrum $(810-1064 \mathrm{~nm})$ is very much consumed by melanin, hemoglobin, and different chromophores that are normally present in periodontal tissues [7, 8]. In diode laser the laser energy can be transmitted through a fiber as small as $600 \mu, 400 \mu$ and $200 \mu$ Diameter Size so that it can undoubtedly infiltrate profound periodontal pockets to convey its restorative impacts [8]. Along with these features, it also has the added advantages such as portability, convenience and cost efficiency. Hence it can be easily incorporated into the dental practice [8]. Diodes dynamic vehicle of aluminum, gallium and arsenide, strong semiconductor working at $810-980 \mathrm{~nm}$. frequencies ingest exceptionally pigmented tissues containing hemoglobin, melanin and collagen chromospheres. This clarifies particular activity of diode lasers on the delicate tissue tasks, for example, cut, vaporization, blood coagulation, curettage and hemostasis than dental hard tissues [9]. Currently most commonly used wavelengths for dental treatment are 810 and $980 \mathrm{~nm}$ [10]. Where $810 \mathrm{~nm}$ frequency is explicit for hemoglobin retention; the $940 \mathrm{~nm}$ frequency gives a decent proportion between the light illuminated into the tissue and the assimilation by hemoglobin and water; the $980 \mathrm{~nm}$ frequency is with the end goal that it is explicit for hemoglobin and water. $[11,12]$. The laser technology for LLLT treatment are mostly used with proper setting of parameters and may be used for the treatment of wound healing, soft tissue injury and relief of pain. Study shows that there may be strong results and weak results of treatment, generally weak results are because of incorrect parameters setting and strong results shows treatment efficacy on healing. 
In This paper the Literature is divided into five section in first section brief introduction has been explained with background of topic. In next section detailed review has conducted from good publications such as Pubmed, Springer, IEEE searched on google search engine. A comparison of clinical study table is designed of Laser diode and its parameters effect on clinical outcomes. Section three shows the applications of laser treatment used for dental treatment. Section four describe various laser diode parameters and their mathematical calculation formulas followed by the conclusion.

TABLE 1: COMPARISON TABLE FOR VARIOUS TYPE OF LASERS USED IN MEDICAL APPLICATIONS.

\begin{tabular}{|c|c|c|c|c|c|c|}
\hline $\mid \begin{array}{l}5 \\
y_{0}\end{array}$ & Laser & Ippe & $\begin{array}{l}\text { Tiareleggh } \\
\text { (uny) Porer } \\
\text { (uti) }\end{array}$ & \begin{tabular}{|l} 
Delinery \\
System
\end{tabular} & Chromoplore & Applications \\
\hline 1 & Argon & Gis & 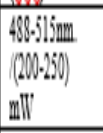 & 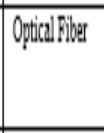 & 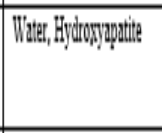 & 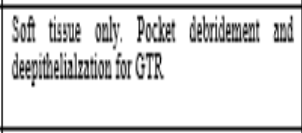 \\
\hline 2 & BeNe & Gis & 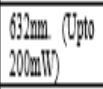 & Optedaliber & 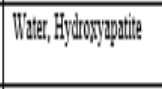 & 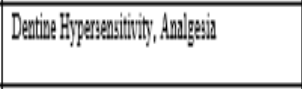 \\
\hline 3 & 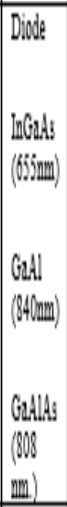 & Solid & 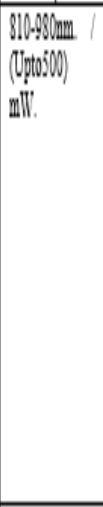 & 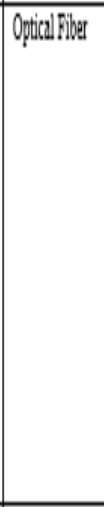 & 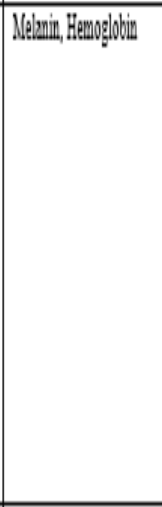 & 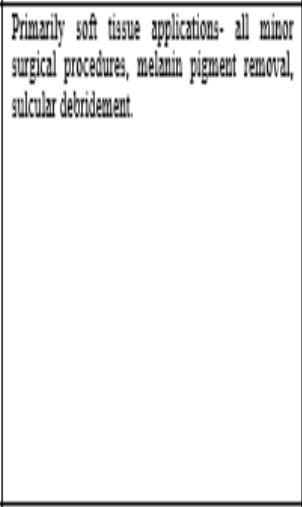 \\
\hline 4 & VAd & Solid & $100 \mathrm{H}$ & Optacalliber & Nelanin, Bemogoldian & 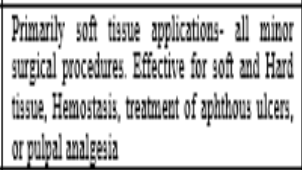 \\
\hline$j$ & \begin{tabular}{|l}
$\mathrm{Hi} \cdot$ \\
$\mathrm{YAO}$ \\
\end{tabular} & Solid & $21210 \mathrm{~m}$ & 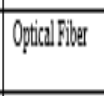 & 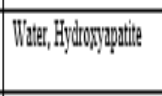 & 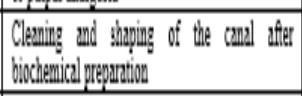 \\
\hline 6 & 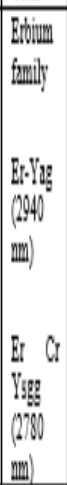 & Solid & $\begin{array}{l}2702940 \\
\text { m }\end{array}$ & Optatalibuter & Witer, Hyitoryypatit: & 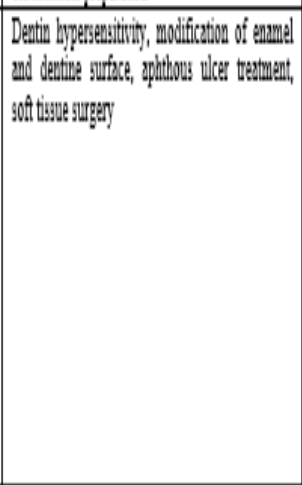 \\
\hline$\sqrt{1}$ & $\mathrm{CO}_{1}$ & Gis & $\begin{array}{l}930,9000, \\
1000=\mathrm{m},\end{array}$ & $\begin{array}{l}\text { Atrudated } \\
\text { Amm, } \\
\text { Wuregidide }\end{array}$ & 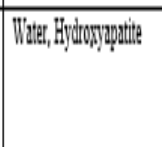 & 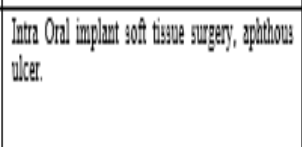 \\
\hline
\end{tabular}

\section{LITERATURE REVIEW}

Study of literature review has been conducted from some scientific research articles and journals available on web science PubMed, Springer, science direct and IEEE. 250 Articles are searched out of which some latest research articles are selected for comparison mainly focused on LLLT using GaAlAs Laser Diode. Figure-1 shows a flow study of review started from search or identification then screening is done on the basis of applications and type of laser used after that full articles are shortlisted for full paper study and only those articles are included in which clinical study is done and results are analyzed with hypothesis testing and compared.

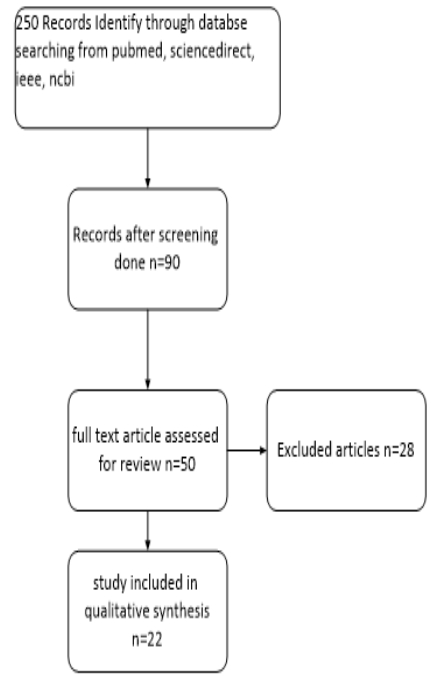

Figure 1: Review Analysis Flow diagram.

Table-2 shows the methods of clinical trials with laser parameters are compared and results shows with proper setting of parameters LLLT provides better results in reducing pain and analgesic effects. This review study shows that Low Level Laser therapy is a wide field of study; many research works has been done on different applications areas with the help of different parameters and wavelengths and much more study needs to be done for different parameter setting at different wavelengths.

TABLE 2: LITERATURE REVIEW TABLE

\begin{tabular}{|c|c|c|c|c|}
\hline $\begin{array}{c}\text { S. } \\
\text { No. }\end{array}$ & $\begin{array}{c}\text { Author } \\
\text { (Year) }\end{array}$ & Methods & Parameters & Outcomes \\
\hline 13. & $\begin{array}{l}\text { Guilherme } \\
\text { Jose et. al., } \\
2020\end{array}$ & $\begin{array}{l}\text { In this paper the } \\
\text { examination } \\
\text { was done to } \\
\text { assess the } \\
\text { osseointegration } \\
\text { of inserts set in } \\
\text { regions united } \\
\text { with various } \\
\text { osteoconductive } \\
\text { bone substitutes } \\
\text { lighted with } \\
\text { infrared low- } \\
\text { level laser } \\
\text { treatment } \\
\text { (LLLT). } \\
\text { Examination of } \\
56 \text {-rodents were } \\
\text { haphazardly } \\
\text { designated into } \\
4 \text { gatherings. } \\
\text { The joined } \\
\text { territories were }\end{array}$ & $\begin{array}{l}\text { GaAlAs } \\
\text { Diode: } \\
\text { 808nm. } \\
\text { Power: } \\
\text { 100mW. } \\
\text { Mode: CW } \\
\text { Laser } \\
\text { irradiated } \\
\text { with laser tip } \\
10 \text { sec. per } \\
\text { point totaling } \\
40 \text { sec. per } \\
\text { session } \\
\text { Energy: } 1 \mathrm{~J} \\
\text { per point } \\
\text { total 4J per } \\
\text { session }\end{array}$ & $\begin{array}{l}\text { LLLT } \\
\text { performed in } \\
\text { areas grafted } \\
\text { with } \\
\text { osteoconductive } \\
\text { bone substitutes } \\
\text { prior to implant } \\
\text { placement } \\
\text { improves } \\
\text { osseointegration } \\
\text { shows that laser } \\
\text { diode device in } \\
\text { IR wavelength } \\
\text { has better } \\
\text { results as } \\
\text { compare to Red } \\
\text { light laser. }\end{array}$ \\
\hline
\end{tabular}




\begin{tabular}{|c|c|c|c|c|c|c|c|c|c|}
\hline & & $\begin{array}{l}\text { treated with } \\
\text { LLLT in } 7 \\
\text { meetings with } \\
48 \text { h between } \\
\text { the } \\
\text { illuminations. }\end{array}$ & & & & & $\begin{array}{l}\text { treated with } 4 \mathrm{~J} \text {, } \\
16 \mathrm{~J} \quad \text { Laser } \\
\text { energy group }\end{array}$ & $\begin{array}{l}\text { dose: } 9 \mathrm{~J} / \mathrm{cm} 2 \\
\text { with } \\
\text { exposure } \\
\text { time } 60 \\
\text { seconds/point }\end{array}$ & $\begin{array}{l}\text { fake treatment } \\
\text { medicines } \\
\text { application. A } \\
\text { poll with a 100- } \\
\text { mm Visual } \\
\text { Analog Scale }\end{array}$ \\
\hline \multirow[t]{3}{*}{14.} & \multirow[t]{3}{*}{$\begin{array}{l}\text { Chong ren et. } \\
\text { al., } 2019\end{array}$} & \multirow[t]{3}{*}{$\begin{array}{l}\text { A randomized } \\
\text { controlled } \\
\text { preliminary } \\
\text { assessment was } \\
\text { done with split- } \\
\text { mouth } \\
\text { configuration } \\
\text { was directed in } \\
27 \text { grown-ups } \\
\text { with rewarded } \\
\text { and controlled } \\
\text { incessant } \\
\text { periodontitis } \\
\text { more than a half } \\
\text { year. }\end{array}$} & \multirow[t]{3}{*}{$\begin{array}{l}\text { GaAlAs } \\
\text { Laser Diode: } \\
\text { 940nm. } \\
\text { Output } \\
\text { Power: } \\
\text { 800mW. } \\
\text { Energy } \\
\text { Density: } 8.6 \\
\text { J/cm2 }\end{array}$} & $\begin{array}{l}\text { Agony is } \\
\text { estimated on } \\
\text { Visual Analog } \\
\text { Scale with score } \\
\text { of } 0 \text { at the left } \\
\text { finish of the } \\
\text { scale designated } \\
\text { 'no torment', } \\
\text { and } 100 \text { at the } \\
\text { correct end } \\
\text { specified 'the } \\
\text { most extreme } \\
\text { torment'. }\end{array}$ & & & & & $\begin{array}{l}\text { (VAS) was } \\
\text { utilized for } \\
\text { torment } \\
\text { appraisal. } \\
\text { Information is } \\
\text { examined by } \\
\text { SPSS. T-test } \\
\text { was utilized to } \\
\text { analyze the } \\
\text { mean torment } \\
\text { scores among } \\
\text { laser and fake } \\
\text { treatment } \\
\text { medicines. }\end{array}$ \\
\hline & & & & $\begin{array}{l}\text { No Adverse } \\
\text { impact is noted } \\
\text { during the } \\
\text { investigation } \\
\text { procedure. The } \\
\text { fake treatment } \\
\text { bunch had a } \\
\text { more prominent } \\
\text { amassing of } \\
\text { plaque at the } \\
\text { gingival edge } \\
\text { than the laser } \\
\text { gathering, and } \\
\text { measurable } \\
\text { hugeness was } \\
\text { appeared at the } \\
\text { 1-month (P < }\end{array}$ & 17. & $\begin{array}{l}\text { May Ayad } \\
\text { Hamid, } 2017 .\end{array}$ & $\begin{array}{l}\text { In this paper the } \\
\text { aim of study is } \\
\text { to evaluate } \\
\text { intraoral LLLT } \\
\text { on } \\
\text { postoperative } \\
\text { pain after } \\
\text { mandibular } \\
\text { third molar } \\
\text { extraction on } 30 \\
\text { Patients } \\
\text { underwent for } \\
\text { surgical } \\
\text { extractions. }\end{array}$ & $\begin{array}{l}\text { GaAlAs } \\
\text { Laser Diode } \\
\text { 810nm. } \\
\text { Power: } 0.1 \mathrm{~W} \\
\text { Mode: CW } \\
\text { Exposure } \\
\text { time 30sec. } \\
\text { Energy: } 9 \mathrm{~J}\end{array}$ & $\begin{array}{l}\text { Introral } 810 \mathrm{~nm} \\
\text { GaAlAs laser } \\
\text { diode is viable } \\
\text { in lessening } \\
\text { postoperative } \\
\text { agony with } \\
\text { portion of } 32.86 \\
\mathrm{~J} / \mathrm{cm} 2 \text {. } \\
\text { Information is } \\
\text { recorded on } \\
\text { visual simple } \\
\text { scale for } 7 \\
\text { progressive } \\
\text { days with } \\
\text { p<=0.05 } \\
\text { significance } \\
\text { level. }\end{array}$ \\
\hline & & & & $\begin{array}{l}0.01) \text { and } 3- \\
\text { month } \\
\text { development ( } \mathrm{P} \\
=0.03 \text { ) visits. }\end{array}$ & 18. & $\begin{array}{l}\text { M. } \\
\text { Honarmand } \\
\text { et. al, } 2017 .\end{array}$ & $\begin{array}{l}\text { Randomized } \\
\text { preliminary is } \\
\text { led to assess the } \\
\text { viability of laser }\end{array}$ & $\begin{array}{l}\text { GaAlAs } \\
\text { Laser Diode } \\
\text { 870nm. } \\
\text { Power: } 80 \mathrm{~W}\end{array}$ & $\begin{array}{l}\text { Torment is } \\
\text { estimated on } \\
\text { Visual simple } \\
\text { scale where } 0 \text { is }\end{array}$ \\
\hline \multirow[t]{2}{*}{15.} & \multirow[t]{2}{*}{$\begin{array}{l}\text { Song Wu et. } \\
\text { al., (2018) }\end{array}$} & \multirow[t]{2}{*}{$\begin{array}{l}\text { In this paper the } \\
\text { creator assesses } \\
\text { the impact of } \\
\text { LLLT on } \\
\text { torment and } \\
\text { somatosensory } \\
\text { sharpening } \\
\text { prompted by } \\
\text { orthodontic } \\
\text { treatment. } 40 \\
\text { people isolated } \\
\text { into Laser } \\
\text { gathering and } \\
\text { fake treatment } \\
\text { gathering. }\end{array}$} & \multirow[t]{2}{*}{$\begin{array}{l}\text { GaAlAs } \\
\text { 810nm. Laser } \\
\text { Diode } \\
\text { Mode: CW } \\
\text { Power: } \\
\text { 400mw } \\
\text { With } 2 \mathrm{~J} / \mathrm{cm} 2\end{array}$} & $\begin{array}{l}\text { The NRS } \\
\text { torment scores } \\
\text { were } \\
\text { fundamentally } \\
\text { lower in the LG } \\
\text { gathering (P = } \\
0.01) \text {. The } \\
\text { CDTs, } \\
\text { CPTs, WDTs, } \\
\text { HPTs, and } \\
\text { PPTs at the } \\
\text { gingiva and the } \\
\text { PPTs at the } \\
\text { canine tooth } \\
\text { were altogether } \\
\text { less touchy on } \\
\text { the treatment } \\
\text { side of the LG }\end{array}$ & & & $\begin{array}{l}\text { diode for the } \\
\text { treatment of } \\
\text { repetitive } \\
\text { herpes, for } \\
\text { clinical trial } 60 \\
\text { patients are } \\
\text { chosen in } \\
\text { isolated into } \\
\text { three gatherings } \\
\text { in which } 20 \\
\text { patients } \\
\text { rewarded with } \\
\text { laser diode and } \\
\text { 20 patients } \\
\text { rewarded with } \\
\text { acyclovir cream } \\
\text { rest } \\
\text { rewarded with } \\
\text { placebo. }\end{array}$ & $\begin{array}{l}\text { Frequency: } \\
600 \mathrm{~Hz} . \\
\text { Energy } \\
\text { Density: } 4.5 \\
\mathrm{~J} / \mathrm{cm} 2\end{array}$ & $\begin{array}{l}\text { no agony and } \\
10 \text { is most } \\
\text { serious torment. } \\
\text { This relative } \\
\text { examination } \\
\text { shows that there } \\
\text { is no factually } \\
\text { huge distinction } \\
\text { seen between } \\
\text { these three } \\
\text { gatherings. laser } \\
\text { diode lessens } \\
\text { the injury size } \\
\text { with no } \\
\text { torment. }\end{array}$ \\
\hline & & & & $\begin{array}{l}\text { contrasted and } \\
\text { that of the } P G \\
(\mathrm{P}<0.033) \text {. }\end{array}$ & 19. & $\begin{array}{l}\text { MAI M. E. } \\
\text { ALMALLAH } \\
\text { et. al, } 2016 .\end{array}$ & $\begin{array}{l}\text { In this paper a } \\
\text { clinical } \\
\text { preliminary }\end{array}$ & $\begin{array}{l}\text { GaAlAs } \\
\text { Laser Diode: } \\
\text { 830nm. }\end{array}$ & $\begin{array}{lr}\text { LLLT } & \text { is } \\
\text { successful } & \text { in } \\
\text { reducing } & \text { post }\end{array}$ \\
\hline 16 & $\begin{array}{l}\text { M. M. A. } \\
\text { Alsayeed } \\
\text { Hassan, } \\
\text { 2017. }\end{array}$ & $\begin{array}{l}\text { In this paper the } \\
\text { evaluation of } \\
\text { LLLT on } \\
\text { Analgesic } \\
\text { effects in } \\
\text { orthodontics } \\
\text { has been done. } \\
26 \text { patients of } \\
\text { orthodontic } \\
\text { treatment } \\
\text { enrolled and } \\
\text { randomly }\end{array}$ & $\begin{array}{l}\text { GaAlAs } \\
\text { Laser Diode } \\
\text { 830nm. } \\
\text { Mode: CW } \\
\text { Power: } \\
\text { 150mW. } \\
\text { Energy: } 2 \mathrm{~J} \\
\text { Dose: } 2.25 \\
\text { J/cm2 } \\
\text { ON time: } 15 \\
\text { seconds/point } \\
\text { Irradiation }\end{array}$ & $\begin{array}{l}\text { Principle result } \\
\text { measure was } \\
\text { the level of } \\
\text { agony scored } \\
\text { during } \\
\text { rumination for } \\
\text { each } \\
\text { mandibular first } \\
\text { molar after } 1,6 \text {, } \\
12,24,48 \text {, and } \\
72 \text { hours of } \\
\text { both laser and }\end{array}$ & & & $\begin{array}{l}\text { appraisal is } \\
\text { performed on } \\
36 \text { patients } \\
\text { somewhere in } \\
\text { the range of } 12 \\
\text { and } 36 \text { years } \\
\text { old. All patients } \\
\text { taught to rate } \\
\text { their agony } \\
\text { level on a } \\
\text { Visual Analog } \\
\text { Scale (VAS). A }\end{array}$ & $\begin{array}{l}\text { Power: } \\
\text { 100mW } \\
\text { Energy } \\
\text { Density: } \\
\text { 4J/cm2. } \\
\text { Spot } \\
\text { Diameter: } \\
7 \mathrm{~mm} \text {. } \\
\text { Irradiation } \\
\text { time: } 28 \\
\text { Seconds per } \\
\text { each } 4 \mathrm{~J} / \mathrm{cm} 2 \\
\end{array}$ & $\begin{array}{l}\text { separation pain } \\
\text { when } \\
\text { experiment is } \\
\text { compared with } \\
\text { the placebo } \\
\text { experiment and } \\
\text { data is analyzed } \\
\text { on VAS } \\
\text { parameter, t-test } \\
\text { and ANOVA is } \\
\text { measured for } \\
\text { statistical }\end{array}$ \\
\hline
\end{tabular}




\begin{tabular}{|c|c|c|c|c|}
\hline & & $\begin{array}{l}\text { line of } 100 \mathrm{~mm} \\
\text { length was } \\
\text { utilized with the } \\
\text { left side } \\
\text { speaking to no } \\
\text { torment (i.e., } \\
\text { score=0) and } \\
\text { right side } \\
\text { speaking to the } \\
\text { most noticeably } \\
\text { terrible agony } \\
\text { (i.e., } \\
\text { score=100). }\end{array}$ & & $\begin{array}{l}\text { analysis of data } \\
\text { with } \\
\text { significance } \\
\text { level } p<0.05\end{array}$ \\
\hline 20. & $\begin{array}{l}\text { Antonio } \\
\text { Crispino et. } \\
\text { al, 2015. }\end{array}$ & 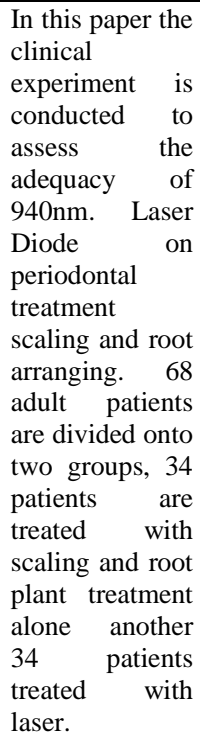 & $\begin{array}{l}\text { GaAlAs } \\
\text { Laser Diode } \\
940 \mathrm{~nm} \text {. } \\
\text { Average } \\
\text { power: 1W } \\
\text { Pulse } \\
\text { Frequency: } \\
\text { 15 Hz. } \\
\text { Mode: Pulse } \\
\text { type } \\
\text { On -time: } 10 \\
\text { ms. } \\
\text { Off-time: } 20 \\
\text { ms. } \\
\text { Optical } \\
\text { diameter of } \\
\text { fiber: } 300- \\
400 \mu\end{array}$ & $\begin{array}{lr}\text { Clinical trials } \\
\text { data statistically } \\
\text { measured with } \\
\text { two tail t-test. } \\
\begin{array}{lr}\text { Both groups } \\
\text { shown }\end{array} \\
\text { significant } \\
\text { differences } \\
\text { compared with } \\
\text { p-value. This } \\
\text { study shows } \\
\text { that gingival } \\
\text { index, plaque } \\
\text { index rand } \\
\text { probing death } \\
\text { decreases } \\
\text { mean in } \\
\text { with value } \\
\text { treatment. laser }\end{array}$ \\
\hline
\end{tabular}

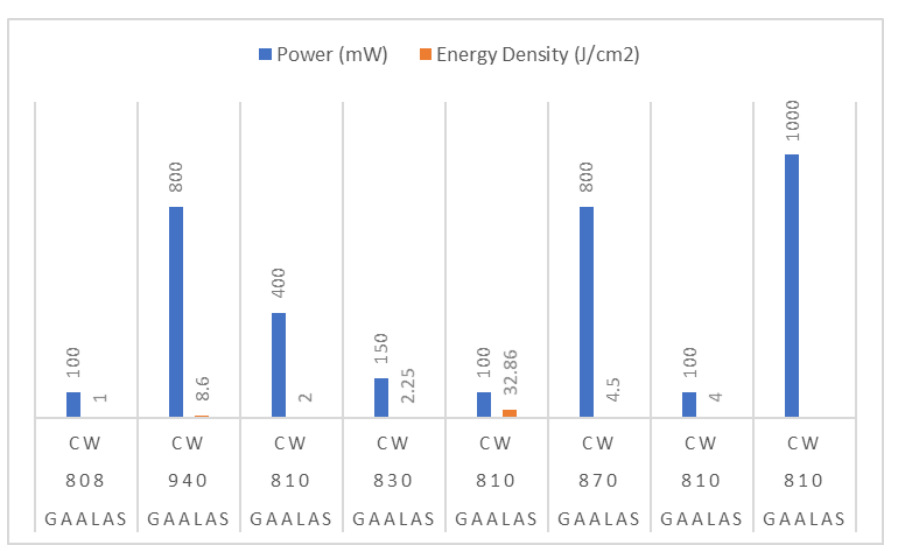

Figure 2: Laser Diode Wavelemgth and Power/Energy chart

\section{APPLICATIONS OF LOW LEVEL LASER THERAPY IN DENTISTRY}

LLLT has a scope of dental, clinical, physiotherapy applications. Low-level laser applications in dentistry remember the advancement of twisted recuperating for a scope of tissues. They are processed in two formats one is for Soft tissue based and others for hard tissue applications. In dental lasers, the laser light is conveyed from the laser to the objective tissue by means of a fiber-optic link, empty waveguide, or explained arm, centering focal points, a cooling framework, and different controls total the framework. The frequency and different properties of the laser are resolved principally by the organization of a functioning medium, which can be a gas, a gem, or a strong state semiconductor.

\section{A. Soft tissue applications}

a) Aphthous ulcers: Low level laser therapy can help to increase the fibroblast proliferation by stimulating the laser light into the wound and ulcers. it can transform the fibroblasts into myofibroblasts which may help in rapid healing of ulcers [21].

Vishal et. al. [22] investigated the use of GaAlAs Laser diode of wavelength $940 \mathrm{~nm}$. With parameters setting $0.6 \mathrm{~W}, \mathrm{CW}$ for 30-45 Seconds for first treatment then $0.7 \mathrm{~W}$, CW for 30-45 seconds for second time treatment, $0.8 \mathrm{~W}$, CW for $30-45$ Seconds for third time treatment after each pass The recordings were made just before the treatment, immediately after treatment, and every 2 days thereafter for a period of 2 weeks. The patients reported that ulcers started healing earlier than in previous attacks; there was also early reduction in pain.

Hershal et. al. [23] investigated the use of a laser device of $500 \mathrm{~mW}$. With wavelength $810 \mathrm{~nm}$. On recurrent aphthous ulcer of 30 patients separated in to two different aphthous ulcers treated with one day, two days, and three days follow up concluded that pain and lesion size reduces with complete healing.

b) Herpes simplex contaminations: herpes simplex contamination is an infected virus which primarily effects the lips area. Laser treatment may help in reducing the herpes infected area by changing the cells and tissue function also decreases healing time.

Priscila et. al. [24] investigated the treatment of LLLT using GaAlAs Laser Diode device of wavelength $780 \mathrm{~nm}$. And $78 \mathrm{~mW}$ Power treated for 80 seconds at four points on the herpes with total dose of $20 \mathrm{~J} / \mathrm{Cm}^{2}$ and concluded that Laser therapy can help in reducing herpes with less pain.

Marina Stella Bello-silva et. al. [25] investigated that the treatment of herpes simplex virus 1 with low and high intensity laser (indium gallium aluminum phosphide, $660 \mathrm{~nm}$, $3.8 \mathrm{~J} / \mathrm{cm} 2,10 \mathrm{~mW}$.), (erbium-doped yttrium aluminum garnet, $2.94 \mu \mathrm{m}, 80 \mathrm{~mJ} /$ pulse, $2-4 \mathrm{~Hz}$ ) concluded that laser can completely heal herpes within 10 days of the treatment.

c) Oral lichen planus: Oral lichen Planus is a chronic disease into the mouth symptoms shows white patches on the inside of cheeks.

O. Mahdavi et. al. [26], investigated that laser therapy with red diode laser of $630 \mathrm{~nm}, 10$ mill watt Power, $1.5 \mathrm{~J} / \mathrm{cm}^{2}$ Dose treated 150 seconds per session every three days during one month concluded effective with decrease in pain and soreness without any side effects.

d) Xerostomia: Xerostomia is not a disease but it causes dryness in mouth reduces saliva may be due to damage of saliva gland. Use of infrared laser shows a noteworthy increment in salivary stream in instances of xerostomia.

Alyne et. al. [27] Investigated that diode laser with parameters $(780 \mathrm{~nm}, 3.8 \mathrm{~J} / \mathrm{cm} 2,15 \mathrm{~mW})$ used to treat xerostomia of 60-year-old woman patient with dry mouth symptoms and Sjögren's syndrome has treated effectively without any side effects.

Bozana et. al. [28] investigated that laser light of pulse Ga-As laser diode with parameters $904 \mathrm{~nm}$. Wavelength 246 $\mathrm{mW} / \mathrm{cm} 2,120$ Sec. per treatment time during 10 days concluded study that laser is effective on salivary glands. 
e) Mucositis: Mucositis is regular finding in the patients who were presented to chemotherapy and radiotherapy for the treatment of threat may Couse ulcer, pain, tissue swelling in the mouth.

T. Zanin et. al. [29] investigated that Laser therapy was performed in combination with radiotherapy and chemotherapy twice a week using a diode laser $(660 \mathrm{~nm}$, power $30 \mathrm{~mW}$., spot size $2 \mathrm{~mm}$, energy $2 \mathrm{~J}$ per point) on 36 patient of laser group with head and neck cancer concluded that laser therapy is effective in mucositis of patient under the treatment of cancer.

Shoheir Shehata et. al. [30] investigated that 3B Laser device produces pulsed infrared GaAs laser with wavelength of 904 $\mathrm{nm}$, peak power of $25 \mathrm{~W}$, pulse duration of $200 \mathrm{~ns}$, and energy density of $1 \mathrm{~J} / \mathrm{cm} 2$. Laser therapy was applied on each point for 1 minute with energy density of $3 \mathrm{~J} / \mathrm{cm} 2$ and treated 80 Patients 6 days/week results concluded Improvement on mucositis for Chemotherapy-induced oral Mucositis (COM).

f) Paresthesia: Paresthesia is a Symptoms of abnormal sensation like pin and needles tingling or burning, prickling sensation in the body. In dentistry paresthesia is one of the complexities of careful treatment, most ordinarily observed after the careful extraction of third molars.

Reneta et. al. [31] Investigated that low power laser of wavelength $808 \mathrm{~nm}$. Effect the recovery of nerve sensitivity after oral surgery.

Icaro Girao et. al. [32] Investigated that laser of wavelength $660 \mathrm{~nm}$. visible red light with parameters $100 \mathrm{~mW}$. Power, 140 $\mathrm{J} / \mathrm{cm} 2$ Energy density, $4 \mathrm{~J}$ of energy application per point $0.028 \mathrm{~cm} 2$ of spot area used for the treatment of paresthesia into inferior alveolar nerve in first session then $810 \mathrm{~nm}$ wavelength laser applied concluded that it helps patient in pain with 9 visual analog score.

g) Periodontitis: Periodontitis is a gum disease that may causes damaging of soft tissues and it can also damage the bone of teeth if not treated on time.

Tanya M. L. et. al. [33] Investigated that a laser diode of wavelength $940 \mathrm{~nm}$. unit (having a maximum power output of $7 \mathrm{~W}$ ) was used with a $7 \mathrm{~mm}$ long, 300-micron diameter, and disposable fiber-optic tip for energy delivery system is applied on 30 patients having chronic to severe periodontitis and concluded that it can help in tissue healing and shows improvement in gingival inflammation.

Lohar Nilam Baburao et. al. [34] Investigated that diode laser of wavelength $980 \mathrm{~nm}$ power $2 \mathrm{~W}$ with treatment time per session of $30 \mathrm{sec}$. in non-contact mode for the treatment of scaling and root planning in periodontitis concluded that root surface slightly altered in the form of cracks.

\section{B. Hard tissue applications}

Dentinal hypersensitivity is a tooth sensitivity when sharp pain arises from exposed of dentine surface in response to thermal, chemical, electrical, osmotic, chemical evaporative stimuli. Marwan el Mobadder et. al. [35] conducted a clinical study to investigate dentinal hypersensitivity using $980 \mathrm{~nm}$ laser diode of $1 \mathrm{~W}$ Power in continuous mode. Graphite is applied on dentine before treatment and total irradiation time depends on removal of this graphite concluded that dentine hypersensitivity reduces safely in a long-term effectiveness.
Temporomandibular disorders are related to the joints of jaw with teeth. Joints are connected with the mandible bone to the temporal bone. Disorder may Couse pain or tenderness around the ear, jaw joint, face and muscles of the jaw.

Ayyildiz S. et. al. [36] Investigated that laser diode of 685 $\mathrm{nm}$. Wavelength $25 \mathrm{~mW}$. Power 0.02 Frequency with Energy density of $6.2 \mathrm{~J} / \mathrm{cm}^{2}$ three times a week for one month with exposure time of 30 seconds concluded that $685 \mathrm{~nm}$. Laser is effective in reducing pain with limited mouth opening of patient.

\section{LASER DIODE AND ITS PARAMETERS}

LLLT right now being followed in all the fortes including orthodontics, wherein it has brought about a superior and patient fulfillment work on, including diminished treatment timings and better outcomes alongside torment decrease methods. It helps in drawing, molding of the delicate tissue, relieving, laser holography and laser welding hemoglobin and it is used in soft tissue applications. Research has shown that the diode laser wavelength $(800-980 \mathrm{~nm})$ is ideally suited for numerous soft tissue procedures due to their high absorption in hemoglobin. This fact gives diode laser the ability to precisely and efficiently cut, coagulate, ablate or vaporize the target tissues. The emitted laser energy is scattered in the target tissues and later converted to heat. Conversely, the energy is poorly absorbed by the hydroxyapatite and by water present in the enamel. Specific procedures appropriate to their use include aesthetic gingival re-contouring, soft tissue crown lengthening, and removal of inflamed and hypertrophic tissue.

Wavelength: Frequency is the most significant determinant in how light influences tissue. It is the separation between two progressive peaks of the wave. Each sort of laser has a specific frequency (or frequencies) as indicated by the idea of the dynamic medium. Laser frequencies are ordinarily estimated in units of length: nanometers $(\mathrm{nm})$ or micrometers $(\mu \mathrm{m})$, contingent upon whether they are in UV, noticeable or IR scope of the electromagnetic range. Essentially expressed, the frequency decides the quality or kind of cooperation between the laser and the tissue. Frequency is a property of photon vitality which is communicated in electron volts $(\mathrm{eV})$. Red photon has $\sim 2 \mathrm{eV}$ vitality and blue photon has $\sim 3 \mathrm{eV}$ vitality.

Mode: Laser may be applying in $\mathrm{CW}$ (continuous wave) mode or in Pulse mode. The CW mode is commonly the quickest method to remove tissues however warmth can develop and make blow-back the objective and neighboring tissues. In Pulse mode beat width is estimated in a given period and the quantity of heartbeats every second, this identifies with the pace of discharge of laser light with time and the prime advantage of a beat mode will be the limit of the objective tissue to cool between progressive heartbeats. Heartbeat wave mode is reliant on the current force setting and Duty Cycle setting.

Pulse duration: Pulse duration is a one of the basic boundaries of laser radiation on tissue or living cells. Heartbeat span is estimated in units of time (milliseconds, microseconds, nanoseconds, picoseconds or femtoseconds). When beat mode is utilized the normal force conveyed will diminish relative to the beat recurrence that is chosen. Setting the beat recurrence 
decide the quantity of laser beats conveyed every second during a beat LLLT treatment. Heartbeat recurrence is estimated in Hertz $(\mathrm{Hz})$. At the point when a low heartbeat recurrence is chosen the interruption between laser beats is more noteworthy so less force is conveyed. At the point when high heartbeat frequencies are chosen there is to a lesser degree a respite between laser beats for example it is nearer to constant yield. The term normal (or mean) power is utilized to depict the net force conveyed in the wake of calculating for both the on and off time of the shaft.Power and power density: Radiant power is the amount of radiant energy. The average power of the laser is equal to the output energy over the exposure time as shown in equation (1):

$$
\text { Average power }=\frac{\text { Energy }}{\text { time }}
$$

In Pulsed Laser:

$$
\text { Average power }=\frac{\text { Energyof the pulse }}{\text { Pulse duration }}
$$

Average power of the pulsed laser or mean power of the chopped laser is equal to the energy of the pulse multiplied by the repetition rate.

For a CW laser the power density is the average output power in watts divided by the irradiated area in square centimeters:

$$
\text { Power Density }=\frac{\text { Average Power }}{\text { Area }}
$$

Peak power of the pulsed laser divided by the irradiated area gives the power density of the pulsed laser:

$$
\text { Power Density }=\frac{\text { Peak Power }}{\text { Area }}
$$

Irradiance: Irradiance is the radiometry term for the power per unit area of electromagnetic radiation incident on a surface. It is radiant energy flux (or power) incident on an element of the surface, divided by the area of the surface.

The power $\mathrm{P}$ that irradiates a surface area $\mathrm{A}$ is called the Irradiance $\mathrm{E}$ :

$$
E=\frac{P}{A} \mathrm{~W} / \mathrm{cm}^{2}
$$

Coherence: Coherence length depends on spectral Bandwidth and coherent light produces speckle are two types of coherence of laser light longitudinal and transverse. The longitudinal type of coherence represents time coherence along the longitudinal beam, whereas transverse coherence refers to coherence across the laser beam.

Polarization: Laser light can be linearly polarized or circularly polarized

Energy and Energy Density: Energy Density is a dose applied for the treatment and it is measured in $\mathrm{J} / \mathrm{cm}^{2}$.

Laser Energy Density is defined as the energy which is delivered per region or active area in $\mathrm{J} / \mathrm{cm}^{2}$ :

$E($ Joule $)=P($ Watt $) *$ Time $($ Sec. $)$
Energy Density $=\frac{P(w) * T\left(s_{\text {sec })}\right.}{\text { Spot size }}$

Spot Size or Irradiation Area: spot size of a laser delivery system implies its littlest measurement at the central plane when centered by a focal point or width and spot diameter across is the diameter of irradiation on the objective surface. The spot distance across is viewed as equivalent to the bar breadth when the focal points are not be utilized. The units of the spot distance across are as a rule in centimeters.

Illumination time: it is the time of exposure to the target tissue.

\section{CONCLUSIONS}

Lasers are unquestionably the future for dentistry as it makes it exceptionally simple to expel the rot. It is useful when arriving at regions that were difficult to treat with customary medicines. There is generally safe of contaminations in and around the treatment region. Low level laser therapy is safe, effective and painless treatment. Many wavelengths of laser diode have been analyzed in Continuous wave mode and in pulse wave mode with irradiation time on dental applications.

\section{REFERENCES}

[1] Mester E, Ludany G, Selyei M, Szende B, Total GJ. "The stimulating effect of low power laser rays on biological systems", Laser Rev. 1968;1:3.

[2] Mester E, Szende B, Gartner P. "The effect of laser beams on the growth of hair in mice", Radiobiol Radiother (Berl) 1968;9:621626.

[3] Kemmotsu O, Sato K, Furomido H, Harada K, Takigawa C, Kaseno $\mathrm{S}$. "Efficacy of low reactive-level laser therapy for pain attenuation of postherpetic neuralgia", Laser Ther 1991; 3:1-75.

[4] Braverman B, McCarthy RJ, Ivankovich AD, Forde DE, Overfield M, Bapna MS. "Effect of helium-neon and infrared laser irradiation on wound healing in rabbits", Lasers Surg Med 1989; 9:50-8.

[5] Midamba E, Haanaes HR. "Therapeutic effect of low-level laser irradiation on inferior alveolar, mental and lingual nerve paresthesia. Laser Therapy", 1993;5:89-94.

[6] S. Stanescu and P. D. Cristea, "Simple Low-Level Laser Therapy device approach," 2012 19th International Conference on Systems, Signals and Image Processing (IWSSIP), Vienna, 2012, pp. 44-47.

[7] Dummett CO, Barens G. "Oromucosal pigmentation: An updated literary review", J Periodontol 1971;42:726-736.

[8] Schwarz F, Aoki A, Sculean A, Becker J. "The impact of laser application on periodontal and peri-implant wound healing", Periodontol 2000 2009;51:79-108.

[9] Maturo P, Perugia C, Docimo R (1939) V 810 d 1 p d. Int J Clin Denitstry 6.

[10] Hitz CB, Ewing JJ, Hecht J. "Introduction to laser technology", 4th ed. Hoboken, N.J: Wiley-IEEE Press; 2012;23-25.

[11] Yu DY, Chen HC, Chang SY, Hsiao YC, Chang CJ. "Comparing the Effectiveness of 1064 vs. $810 \mathrm{~nm}$ Wavelength Endovascular Laser for Chronic Venous Insufficiency (Varicose Veins). Laser Therapy", 2013;22:247-253.

[12] Olivi G, Genovese MD, Caprioglio C (2009), "Evidence-based dentistry on laser paediatric dentistry: Review and outlook". Eur J Paediatr Dent 10: 29-40.

[13] de Oliveira, G.J.P.L., Aroni, M.A.T., Pinotti, F.E. et al. "Low-level laser therapy (LLLT) in sites grafted with osteoconductive bone substitutes improves osseointegration" Lasers Med Sci (2020). https://doi.org/10.1007/s10103-019-02943-w

[14] Ren, C., McGrath, C., Gu, M. et al. "Low-level laser-aided orthodontic treatment of periodontally compromised patients: a randomised controlled trial. Lasers Med Sci (2019)". https://doi.org/10.1007/s10103-019-02923-0

[15] Wu, S., Chen, Y., Zhang, J., Chen, W., Shao, S., Shen, H., Wang, K. (2018). "Effect of low-level laser therapy on tooth-related pain and somatosensory function evoked by orthodontic treatment", 
International Journal of Oral Science, 10, [22]. https://doi.org/10.1038/s41368-018-0023-0

[16] AlSayed Hasan M. M. A., Sultan K., Hamadah O. "Evaluating lowlevel laser therapy effect on reducing orthodontic pain using two laser energy values: a split-mouth randomized placebo-controlled trial", European Journal of Orthodontics. 2017 doi: 10.1093/ejo/cjx013.

[17] Hamid MA. "Low-level Laser Therapy on Postoperative Pain after Mandibular Third Molar Surgery. Ann Maxillofac Surgery". 2017;7(2):207-216. doi:10.4103/ams.ams 5

[18] Honarmand, Marieh et al. "Comparing the effect of diode laser against acyclovir cream for the treatment of herpes labialis." Journa of clinical and experimental dentistry vol. 9,6 e729-e732. 1 Jun. 2017, doi:10.4317/jced.53679

[19] Almallah M. M. E., Almahd W. H., Hajeer M. Y. "Evaluation of the use of low-level laser therapy in pain control in orthodontic patients: A randomized split-mouth clinical trial. Journal of Clinical and Diagnostic Research". 2016; 10(11): ZC23-ZC28. doi: 10.7860/JCDR/2016/22813.8804.

[20] Crispino A, Figliuzzi MM, Iovane C, Del Giudice T, Lomanno S, Pacifico D, et al. "Effectiveness of a diode laser in addition to nonsurgical periodontal therapy: Study of intervention", Ann Stomatol (Roma) 2015;6:15-20

[21] Babu B, Uppada UK, Tarakji B, Hussain KA, Azzeghaibi SN, Alzoghaibi I. "Versatility of diode lasers in low-level laser therapy for the management of recurrent aphthous stomatitis". J Orofac Sci 2015;7:49-53

[22] Anand V, Gulati M, Govila V, Anand B. "Low level laser therapy in the treatment of aphthous ulcer". Indian J Dent Res 2013; 24:267-70.

[23] Aggarwal, H. Singh, M. P., Nahar, P. Mathur, H. GV, S. (2014). "Efficacy of Low-Level Laser Therapy in Treatment of Recurrent Aphthous Ulcers - A Sham Controlled Split Mouth Follow Up Study", 8(2), 218-221.

[24] Stona P, da Silva Viana E, dos Santos Pires L, Weber JBB, Kramer PF. "Recurrent Labial Herpes Simplex in Pediatric Dentistry: Lowlevel Laser Therapy as a Treatment Option”, Int J Clin Pediatr Dent 2014;7(2):140-143.

[25] Bello-Silva, M.S., de Freitas, P.M., Aranha, A.C., Lage- Marques, J.L., Simoes, A., and Eduardo, C de P. (2010) "Low and highintensity lasers in the treatment of herpes simplex virus 1 infection". Photomed. Laser Surg. 28, 135-139.

[26] Mahdavi, O., Boostani, N., Jajarm, H., Falaki, F., \& Tabesh, A. (2013). "Use of low level laser therapy for oral lichen planus: report of two cases". Journal of dentistry (Shiraz, Iran), 14(4), 201-204.

[27] Simões A, Platero MD, Campos L, Aranha AC, Eduardo Cde P, Nicolau J. "Laser as a therapy for dry mouth symptoms in a patient with Sjögren's syndrome: a case report". Spec Care Dentist. 2009;29(3):134-137. doi:10.1111/j.1754-4505.2009.00078.

[28] Lončar B, Stipetić MM, Baričević M, Risović D. "The effect of lowlevel laser therapy on salivary glands in patients with xerostomia”. Photomed Laser Surg. 2011;29(3):171-175. doi:10.1089/pho.2010.2792

[29] Zanin T, Zanin F, Carvalhosa AA, et al. "Use of 660-nm diode lase in the prevention and treatment of human oral mucositis induced by radiotherapy and chemotherapy". Photomed Laser Surg. 2010;28(2):233-237. doi:10.1089/pho.2008.2242.

[30] Rezk-Allah, S. S., Abd Elshaf, H. M., Farid, R. J., Hassan, M., \& Alsirafy, S. A. (2019). "Effect of Low-Level Laser Therapy in Treatment of Chemotherapy Induced Oral Mucositis". Journal of lasers in medical sciences, 10(2), 125-130. https://doi.org/10.15171/jlms.2019.20

[31] de Oliveira RF, da Silva AC, Simões A, Youssef MN, de Freitas PM. "Laser Therapy in the Treatment of Paresthesia: A Retrospective Study of 125 Clinical Cases". Photomed Laser Surg. 2015;33(8):415-423. doi:10.1089/pho.2015.3888.

[32] Girão Evangelista, I., Pontes Tabosa, F. B., Bezerra, A. V., \& de Araújo Neto, E. V., Jr (2019). "Low-Level Laser Therapy in the Treatment of Inferior Alveolar Nerve Paresthesia After Surgical Exeresis of a Complex Odontoma". Journal of lasers in medical sciences, 10(4), 342-345. https://doi.org/10.15171/jlms.2019.55.

[33] Lobo TM, Pol DG. "Evaluation of the use of a $940 \mathrm{~nm}$ diode laser as an adjunct in flap surgery for treatment of chronic periodontitis". J Indian Soc Periodontol 2015:19:43-8
[34] Baburao LN, Neelkanth BG, Vivek HR, Dilip MS. Effect of diode laser on periodontally involved root surfaces: $A n$ in vitro environmental scanning electron microscope study. J Dent Lasers 2014;8:2-7

[35] El Mobadder, M., Namour, A., Namour, M., Dib, W., El Mobadder, W., Maalouf, E., Geerts, S., Zeinoun, T., \& Nammour, S. (2019). "Dentinal Hypersensitivity Treatment Using Diode Laser $980 \mathrm{~nm}$ : In Vivo Study", Dentistry journal, 7(1), 5 https://doi.org/10.3390/dj7010005.

[36] Ayyildiz S, Emir F, Sahin C. "Evaluation of Low-Level Laser Therapy in TMD Patients", Case Reports in Dentistry. 2015;2015:424213. DOI: $10.1155 / 2015 / 424213$ 